\title{
EFL Teachers' Competence in the Context of English Curriculum 2004: Implications for EFL Teacher Education
}

\author{
Nenden Sri Lengkanawati \\ Indonesia University of Education
}

\begin{abstract}
This is a report of a study which was intended to respond to criticism of the English Curricula used in Indonesia which claimed by some as failure to make Indonesian students ready in competing with those from other nations. The study tried to portray EFL teachers' competence in West Java and the implications for teacher education. Using a descriptive method, the study investigated proficiency of English teachers in West Java as a tool to assess their readiness in facing the challenge of the implementation of the 2004 English Curriculum and its implication for teacher education. The data concerning teachers' proficiency in Listening, Structure, and Reading Comprehension were collected using a TOEFL-equivalent test, while the writing skill was gained through writing test. Interviews were used to gather information concerning lems faced by the teachers in the implementation of and their perception on the new curriculum. The data were then analyzed, described, and interpreted analytically. It was found that the qualification of the majority of the teachers was not yet at a level of presumably sufficient to implement the 2004 curriculum successfully.
\end{abstract}

Key words: teachers' competence, English Curriculum, teacher education

It has been so long that the teaching of English in Indonesia is considered as failing in developing learners' competence in the target language. The criticism most of the time is related to the weaknesses of the students who are considered as not being able to communicate in the target language, both in oral and written production. The failure is supported by the fact that many 
high school leavers, even university graduates, fail to gain sufficient mastery of English to understand references written in English. Lengkanawati (2002) observes in her research at the Language Center she manages that from 286 students-candidates who took TOEFL equivalent in the entrance test required to enroll in the graduate programs at the Indonesia University of Education for the Academic year 2002/2003, only $18.18 \%$ of the test takers gained TOEFL score above 500 .

Hamied (2001a) states that overall the teachers' English competence is below level of adequacy. At the lower secondary schools, there are $42.74 \%$ teachers with a bachelor degree or higher; $46.91 \%$ with a diploma; and $10.35 \%$ with an upper secondary school diploma. He believes that very often degrees do not necessarily correlate positively with the actual language and teaching competence. Besides teachers' competence there are also other factors which should be responsible for the failure of the English teaching. In his research, it was found that the farther the location of the school was from big cities, the less adequate the teacher's English competence would be.

The questions lingering are whether the failure is due to teachers' competence as a result of teacher education training which has put too much emphasis on how to teach but not on what to teach. Woodward (1991) confirms that two things will be especially important if we are going to train teachers of English as a foreign language. The first one is content that is what information, skills, or knowledge to be taught and the second one is process, that is how this knowledge is going to be taught or what vehicle to be used to convey the content. The easiest way in responding to this question, most of the time is by blaming the curriculum. Changing and modifying the curriculum might be considered easier than improving the teachers' quality and emending the teacher education program. We are fully aware that no matter how good and well developed a curriculum is if it is implemented by under qualified teachers it would not resuit in fruitful outcome. The development of the new curriculum-the 2004 Curriculum, which is now being implemented in schools in Indonesia was meant to rectify the failure of the teaching of English in Indonesia.

The present curriculum was also meant to answer the criticism of the previous English Curricula used in Indonesia which have been claimed by some as failure to make Indonesian students ready in competing with those from other nations. Will the new curriculum successfully answer the criticism? It is believed that curriculum revision is needed, among others, to create relevance to the existing demand of the society. Lengkanawati (2004) states that curriculum revision would not be effective if it is not accompanied by other necessary efforts to improve education as a whole. There are some sectors in our current education system which need handling very badly at the moment on the top of priority, that is the teachers who are the forefront implementers of the curriculum. Many experts have raised doubt about the teachers' competence in understanding and implementing the 2004 Curriculum, which has set up high competencies.

The implementation of curriculum needs some supporting factors such as teachers 'familiarity of the curriculum being implemented and teachers' competence. Questions raised by experts and practitioners alike are whether teachers as the forefront implementers are well-prepared professionally to put the curriculum into classroom reality? The answer to this will entail necessity to see into various other aspects that would contribute to the success of the curriculum implementation.

Teachers in Indonesia constitute the largest size of educational personnel, They play a very strategic role in our national building and development. Nevertheless, quantitative fulfillment does not always automatically guarantee the qualitative fulfillment (Hamied, 2001b). Improving teacher's quality is not a simple affair since it relates to and is to be supported by multi-dimensional factors. When we intend to, improve the teaching of English in our schools we have to, among others, lift up teacher's competence through a well designed and organized teacher education program.

As regards the significant role of teachers' competence in the implementation of the present curriculum, teachers, of course, should be familiar with the competencies expected by the curriculum. Implicitly, the objective of English instruction in secondary schools was geared to the attainment of communicative competence. In its broadest sense, the term communicative competence consists at least of four components: grammatical competence, sociolinguistic competence, discourse competence, and strategic competence (Canale 1983 in Oxford 1990). The latest models of competence in the language literature put forward by Celce-Murcia, Dornyei and Thurrell (1995) as quoted in the 2004 Curriculum has been chosen to underlie the existing curriculum. This model is developed for the purpose of language pedagogy, which includes five components: (1) discourse competence, (2) linguistic competence, (3) actional competence, (4) sociocultural comptence, and (5) strategic competence with the shift of paradigm in that the ultimate compe- 
tence of the communicative competence is discourse competence.

A better trained teaching force is an important factor in educational quality and efficiency. The proportion of the teaching force meeting national qualification standards differs markedly between countries. In terms of formal qualification, Indonesia is better than any other developing countries as most teachers have formal qualifications, as indicated in Table 1 below. More than $85 \%$ of the primary and upper secondary school teachers in Indonesia have formal tertiary level qualification (see Table 1).

Table 1. Share of teachers with tertiary-level qualifications, 1998 (in percentage)

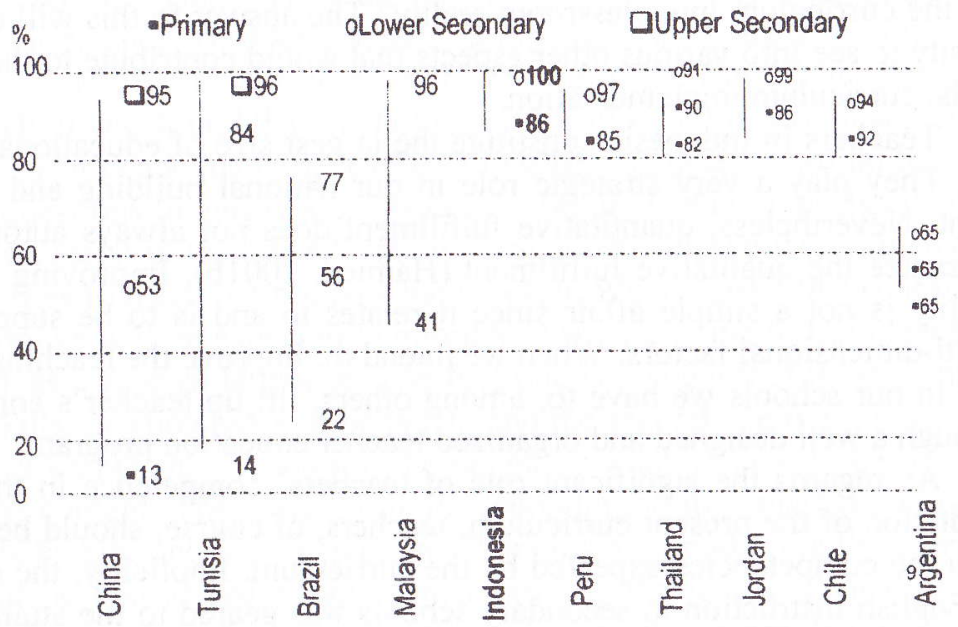

Source: Education at a Glance OECD Indicators 2004, p.390

Formal qualification of teachers is not always linked to their teaching competence and as the 2004 curriculum has been developed in the spirit of Law No 20/2003, teachers' qualification and competence become very important factors in improving schools' performance. Thus, the study reported in this paper portrays English competence of EFL teachers as an instrument to assess their readiness in implementing the new curriculum and its implication for the improvement of teacher education at the university level.

\section{RESEARCH METHODS}

A descriptive method was utilized in this study to investigate the proficiency of English teachers in West Java in the context of assessing the teachers' readiness in the implementation of the 2004 English Curriculum. The test instruments which were used to assess the teachers' competence in English were a TOEFL equivalent test and a writing test which were administered to a sample of 66 teachers coming from junior and senior high schools in West Java. Out of the 66 subjects in the study only 38 were analyzed as they were the ones who completely accomplish both the proficiency and written tests. In addition to the testing instruments, an interview was also conducted to selected teachers to gain information regarding problems faced by the teachers, their perception on the new curriculum, and their expectation concerning the content and ways of pre and in-service trainings which could enhance the implementation of the new curriculum. The data were then analytically described, analyzed, and interpreted as they were relevant to issues and problems in the teaching of English based on the 2004 English.

\section{FINDINGS}

It was found that teachers' competence in the four language skills of most junior and senior high school teachers involved in the study had not reached a level expected from the teachers to be ready for the implementation of the present curriculum. Close to $50 \%$ of the teachers in the sample had competence that could be categorized as inadequate for the implementation of the curriculum (see Table 2). The average TOEFL-equivalent score that they gained was only 467 ranging from the lowest one which was 290 to the highest of the score which was 587. In the listening section, the teachers on the average could only answer 16 items or $35.58 \%$ correctly out of 40 items they had to work on. In the structure and written expression section, they could manage answering the questions better than in the listening comprehension part. In this part, the teachers on the average could answer 26 items correctly or $65 \%$ of the items covered. The teachers' ability in Reading Comprehension section on the average was lower than in the Structure section. They, on the average, could only answer 29 questions or $58.73 \%$ of the 50 questions that should be answered. The teachers' proficiency in English is displayed in Table 2. 
Table 2. Teachers' Proficiency

\begin{tabular}{ccc}
\hline Score & $\mathbf{n}$ & $\%$ \\
\hline $200-449$ & 16 & 42.10 \\
\hline $450-500$ & 11 & 28.95 \\
\hline $501-$ more & 11 & 28.95 \\
\hline
\end{tabular}

The data in Table 2 show that there are only 11 teachers or $28.95 \%$ of the 38 teachers whose TOEFL score is above 500,11 teachers or $28.95 \%$ is between 450 and 499 , and 16 teachers or $42.10 \%$ between 290 and 449 . This finding indicates that the teachers' competence is far below the expected competence. Most teachers are only adequately proficient in structure but not sufficiently proficient yet in listening and reading. Overall, their level of proficiency with the average of 467 is still below 500 based on the TOEFLequivalent scoring standard, an indicator of very probably inadequate proficiency.

The teachers' competence in writing seems to be inadequate. Most essays written by the teachers still contained weaknesses in almost all aspects of good writing such as content, organization, vocabulary, grammar, and mechanic. The respondents' essays were analyzed using ESL Composition Profile put forward by Jacobs et al (1981). Content-wise most essays written by the teachers in the sample showed their limited knowledge of the subject written and with little substance and inadequate development of the topic. Most respondents did not use facts or other pertinent information to support their argument. The thesis in their writing was not expanded properly and sufficiently to convey a sense of completeness. The following unedited essay is an example of a very poor writing of a teacher in the sample which indicates little substance and inadequate development of the topic

My opinion education expensive for examples if we want to enter school we must out a lot of money, although want to enter kindergarden. I think education should be a good not always be cheap or expensive not always to look from the matherial but we must to look the attitude one of school.

(A teacher in a public high school in Bandung)
In terms of the organization of their writing, most essays indicate that the writers are not capable of organizing their ideas and they lack logical sequencing and development. The ideas in their writing did not flow to build a coherent essay. In some essays, there were even no clearly stated controlling idea or central focus and none of their essays was without digression. Moreover, several essays consist of only one very long sentence consisting of more than 100 words so that their essays contain mainly run-on sentences. An example of a teacher's writing with run-on sentences can be seen in the following unedited essay.

I believe that education need fees to suport more quality so I can if education is expensive because we need everything to suport edu cation in good quality as we know that everything that we need is expensive too for example: we need some books, we need up grade tools or medias transportations 100, and also we need good resources or experts and we have to develop the human resources that need research to know wether the result is fail and not we have to do that if we want to get good quality in anything we've done. So it's logic if we say that education is expensive.

(A teacher in a public high school in the city of Bandung)

The respondents' essays show that they could not use their knowledge of vocabulary productively. Most of them used limited range of vocabulary. They frequently made errors of word forms, choice, and usage. Sometimes the meanings were not clear and very often confusing. The data show that, even the respondents whose TOEFL score was above 500, they could not use the sophisticated range of vocabulary in their writing. Many teachers could not use words in their correct forms with regard to the structural functions of the words in the sentence. For example an adjective was used in a place for a noun; a verb form was placed in a nominal position; articles were used when they were actually unnecessary. The following unedited essay by one of the teachers illustrates the errors.

The education shoud be expensive because the education is very important for every people or every citizen in Indonesia. Sometimes if the education too cheap we considered that the education that the education is lower. The important of education for: The in- 
crease intelectual so that the people become smart. Indonesian people that education didn't do with the best, because Indonesian curriculum still be changed. The education should be expensive, should be used media for example computer, internet, many books and so on. I agree with the education should be cheap so that the Indonesian people can study very well.

(A teacher in a private high school in Bandung)

The above examples of essays written by some of the teachers also indicate grammatical mistakes and problems in the mechanic of writing. Grammatical mistakes could be found not only in the respondents' essays whose TOEFL score below 450 but also in the respondent essays whose TOEFL score were between 450 and 500 . The major problems are in the simple as well as complex constructions. Errors of negation, agreement, tense, word order, word function, articles, prepositions. Fragments and runons which made the meaning of the sentences were confusing were frequently found in their writing.

Good writing should be constructed by correct mechanic of writing, Many essays were written using poor mechanic. Error in spelling, punctuation, capitalization, paragraphing, and poor handwriting were found in some of their essays. These errors made the meaning of the essays unclear and confusing. From the data collected, it could be concluded that the respondents very probably rarely write compositions, not only in English but also in their native language as can be seen not only are they weak in linguistic aspects of writing but also in such logical aspects as content and organization.

Interviews with some secondary school teachers have revealed difficulties experienced by the teachers in understanding and implementing the curriculum as well as evaluating achievement of the students in the classroom. The teachers admitted that guidelines for the implementation had varied a lot so that selection of which guidelines to implement became difficult. Techniques of teaching introduce in the new curriculum were not yet specific enough for the teachers to choose. This situation could be even worse as most teachers had to handle big classes consisting of more than 45 students with average teaching loads of at least 18 hours a week.
The mechanism of quarterly reports also made the teachers fully occupied by their work. In one of the pilot school, the teachers, including English teachers of course, there were two types of scoring systems, using score grades as well as narrative reports. Consequently, the teachers were very busy filling out the forms provided by the schools for the narrative report for every individual student to be reported to the parents. For the students who could not perform well in the tests, the teachers should also provide extra time for remedial teaching. This made the teacher even much busier than they could manage.

Other problems encountered were not only the ones faced by the teachers but also complaints raised by the students. According to the teachers, their students complained that the activities assigned to them were time and money consuming. Another problem admitted by the students had something to do with the learning environments which were not conducive to make the students have adequate exposure to native English speakers. The students also felt that they were too busy working on homework assignments provided by each subject. The teachers were now thinking of doing it across the curriculum. Instead of asking the students to do different types of tasks for one subject, each teacher collaborated with other teachers from different subject matters in developing the task activities for the students.

\section{DISCUSSION}

As a result of the adopted concepts underlying the new curriculum, competencies expected from the learners of English in our school as it is explicitly stated in the 2004 curriculum are considered to have been set too high. The expected competencies which are explicitly stated in the curriculum include the ability to communicate fluently and accurately in the spoken and written language by using appropriate language varieties in the form of interactional and monologue discourses which include description, narration, spoof/recount, procedures, reports, news items, anecdotes, exposition, explanation, discussion, commentary, and reviews (Depdiknas, 2003). Consequently, the expected competencies should of course first be possessed by the teachers who are going to be in charge of the teaching and learning activities in the classrooms. When the competencies cover the ability to communicate in both speaking and writing by using appropriate language varie-
ties, this would entail the development of the language skills which are very 
close to native-like ability.

The promulgation of the New Education Law (UU No. 20/2003) has been effective since 11 July 2003. This has signaled a new era of TEFL in Indonesia. With this new law being enforced, major changes should occur in our practices of teaching English in schools. This Law implies reforms to be conducted in our profession. Two articles of this Law are related, whether directly or indirectly, to our profession. First, the mandate to establish at least a school of international standard in every province (Article 50), which will in turn require teachers who can teach bilingually (at least using two languages-Indonesian and English), implies that probably half of the teachers, especially those teaching mathematics and science, should be able to use English as the medium of instruction. In relation to this, in Article 33, verse 3 , it is stated that a foreign language can be used to support the development of learners' foreign language skills. Lifting up the teachers' competence in the implementation of the present curriculum is very urgent to respond to the new law.

Referring to the two articles in the Education Law articles 33 and 50, EFL teacher education institutions should then respond timely to this new policy. This is a real professional challenge. How can the new policy make significant contribution to teacher education programs which will ensure that the student teachers can learn how to communicate in English while they are teaching? The answer to this question can be obtained through intensive discussions among experts involved in the teaching of English as a foreign language to specifically outline professional steps and procedures $n$ improving teachers through different types of training and education: pre-service, inservice as well as on-service.

The findings above have indicated weaknesses on the part of the teachers in almost all aspects of English proficiency. The data has shown that the teachers' competence in writing seems to be inadequate. Apparently, it is doubtful that the teacher would be capable of bringing students to have expected competence in writing as listed in Curriculum 2004. Most essays written by the teachers still contain weaknesses in almost all aspects of good writing such as content, organization, vocabulary, grammar, and mechanic.

The fact that the English teachers' competence is far from expected competencies listed in the curriculum would raise a question if it has anything to do with the teachers' welfare. As a matter of fact, when we compare teachers' salaries in some Asian countries, we can see that our teachers' sala- ries rank lowest with almost one tenth of those gained by their colleagues teaching in primary schools in Malaysia, and one third when compared to Sri Lanka. Korea tremendously exceeds all other countries in this respect (see Table 3).

Table 3. Teachers' salaries: annual, in public institutions at starting salary in equivalent US dollars

\begin{tabular}{lccc}
\hline \multicolumn{1}{c}{ Countries } & Primary & Lower Sec & Upper Sec \\
\hline Indonesia & 975 & 975 & 1,014 \\
Malaysia & 9,344 & 13,647 & 13,647 \\
Philippines & 9,857 & 9,857 & 9,857 \\
Sri Lanka & 2,809 & 2,809 & 3,574 \\
Thailand & 5,862 & 5,862 & 5,862 \\
Korea & 26,983 & 26,852 & 26,852 \\
\hline
\end{tabular}

Unpleasant reward in the teachers' career should not impede the effort in lifting up the quality of education with the hope that in future teachers' salary would also be standardized. It has been mentioned earlier that when we intend to improve the quality of education we should first improve the teachers' competence. Teachers' competence would then require standardization as a result of the stipulation of the national standard of education in Education Law No 20, article 35. Since the national standards of education should cover the standards for content, processes, exit competencies, teachers, facilities and equipment, management, and educational assessment and evaluation, teacher education should respond to this new policy by looking into each aspect of education to be standardized. In this respect, no exception applies for English teacher education to set up a standardized list of teacher competencies developed and inculcated in a standardized teacher education system.

It is certainly true that a better trained teaching force is an important factor in maintaining educational quality and efficiency especially in the implementation of a curriculum in relation to the quality of learning outcome. 
Therefore, as teachers play a significant role in implementing the curriculum, their competence becomes a crucial factor in making the implementation efforts successful.

Another problem encountered is not directly faced by the teachers but has something to do with the students. According to the teachers. interviewed, their students complained that the activities assigned to them were time and money consuming. The students basically reflect typical Indonesian learners with specific characteristics. They are not used to working hard in their learning process. Lengkanawati (1996) in her research report describes that almost $90 \%$ of her respondents admit that they will work for their study only when they have to face tests.

The findings above has shown data describing insufficient proficiency in English among school teachers. To respond to this particular issue there is a need of all existing teacher education institutions to set up standards within their institutions that cover standards in the teaching learning process, student assessment, learner characteristic recognition, teachers' English language proficiency, and TEFL professionalism. It also seems to be imperative as well that involvement of a greater number of teachers in many different types of in-service training in the district level and sub-district level take place and be managed in a professional manner.

\section{CONCLUSIONS AND SUGGESTIONS}

In order to improve the students' ability to communicate in English as prescribed in the curriculum, they have to be exposed to the English textthe spoken and written language that are developed to achieve different communicative purposes. Therefore we need teachers who can totally implement the new curriculum in order to facilitate the development of discourse competence.

To materialize the expectation mentioned above, teachers' in-service training should be designed to cater to a greater number of EFL teachers by offering different types of training in the district level and even in the subdistrict level. The training should be tailored to, first of all, facilitate the teachers to understand the new curriculum well so that they can make use of the curriculum to enhance and strengthen their teaching activities.
It could also be concluded that the problems encountered in the implementation level could also be due to the level of insufficient proficiency of the teachers. The data indicated that most teachers involved in this research were very weak in listening and writing ability. Therefore the training and education of the teachers should include materials and activities that will improve the teachers' competence in the four language skills as well as the professional skill of how to assist the students in developing those skills.

Because the teachers' difficulty also took place in the aspect of evaluation, the training and education of teachers should also cover the material to help teachers get familiar with specific assessment types as recommended by the new curriculum such as portfolio assessment. Portfolio assessment is considered by most teachers not effectively and efficiently applicable yet in the Indonesian contexts considering the big classes in the secondary school level in Indonesia and the heavy teaching loads of the teachers. Last but not least, to improve the quality of English education in Indonesia, the teachers' competence could also be improved by a more competitive and selective teacher recruitment process. In other words the recruitment mechanism should be reviewed and reassessed in a professional fashion. Only teacher candidates with proficient English could be hired to become English teachers.

\section{REFERENCES}

Agustien, Helena I. R. 2003. Setting up New Standards: A Preview of Indonesian's New Competence-Based Curriculum. A paper presented at International TEFLIN Seminar, 21-23 October 2003.

Celce-Murcia, Marianne; Dornyei, Zoltan; and Thurrell, Sarah. 1995. Communicative Competence: A pedagogical Motivated Model with Content Specifications. In Issues in Applied Linguisticvs, 6/2, pp 5-35.

Departemen Pendidikan Nasional. 2003. Kurikulum Berbasis Kompetensi Standar Kompetensi Bahasa Inggris. Jakarta.

Hamied, Fuad A. 2001 a. English Language Education in Indonesia. A paper presented at the East-West Center and Ohana Foundation Workshop on Increasing Creativity and Innovation in English Language Education East-West Center, Honolulu, Hawaii, February 16-27, 2001. 
Hamied, Fuad A. 2001b. Regional Autonomy and the 1994 English Curriculum. A paper presented in the Language Teaching Seminar organized by English Education Department Student Association on the Campus of Indonesia University of Education, 11 March 2001.

Hamied, Fuad A. 2003. National Education System, Regional Autonomy and TEFL in Indonesia. A paper presented at the First Asia TEFL International Conference, 7 - 9 November 2003.

Harmer, Jeremy. 2002. The Practice of English Language Teaching. Malaysia:Pearson Education Limited.

Hedge, Tricia. 2001. Teaching and Learning in the Language Classroom. Hong Kong: Oxford University Press.

Huda, Nuril. 1999. Language Learning and Teaching. Issues and Trends. Malang: Penerbit IKIP Malang.

Jacob, H. L. et al. 1981. Testing ESL Composition: A Practical Approach. Rowley, Massachusetts: Newbury House Publisher. Inc.

Lengkanawati, Nenden Sri. 2002. Kurikulum Berbasis Kompetensi. A paper presented at a Workshop Teaching Models Based on CompetencyBased Curriculum, November 2002.

Lengkanawati, Nenden. 1996. Kontribusi Strategi Bejaran Bahasa terhadap Kemahiran Berbahasa Inggris sebagai Bahasa Asing dan Bahasa Indonesia sebagai Bahasa Asing. Unpublished Dissertation. Universitas Pendidikan Indonesia.

Lengkanawati, Nenden. 2004. Teachers' Competence in Implementing Competency-Based Curriculum. Presented in the UPSI International Conference, Kuala Lumpur Malaysia August 2004.

Mc Kay, P. et al. 2001. Language Standards: An International Perspective. TESOL Matters, Vol. 11, No. 2, March/April/May 2001.

OECD. 2004. Education at a Glance OECD Indicators 2004.

Oxford, Rebecca L. 1990. Language Learning Strategies. Boston: Heinle \& Heinle Publishers.

Richards, Jack C. 1999. Longman Dictionary of Language Teaching \& Applied Linguistics. Edinburg: Pearson Education Limited.

Stern, H. H. 1994. Fondamental Concepts of Language Teaching. Oxford: Oxford University Press.

Woodward, Tessa. 1991. Models and Metaphors in Language Teacher Training: Loop input and other strategies. Great Britain: Cambridge University Press. 